\title{
SISTEM KEPERCAYAAN PADA KOMUNITAS ADAT KAJANG \\ DESA TANAH TOWA KECAMATAN KAJANG KABUPATEN BULUKUMBA
}

\section{BELIEF SYSTEM IN INDIGENOUS COMMUNITY OF KAJANG IN THE VILLAGE OF TANAH TOWA, DISTRICT OF KAIANG, REGENCY OF BULUKUMBA}

\author{
Oleh Abdul Hafid \\ Balai Pelestarian Nilai Budaya Makassar \\ Kementerian Pendidikan dan Kebudayaan \\ Jln. Sultan Alauddin Km 7 Makassar \\ Telp.(0411)883748/885119,Fax (0411)883734 \\ Email: abdulhafid29@yahoo.com
}

\begin{abstract}
Abstrak
Tulisan ini mendeskripsikan sistem kepercayaan asli komunitas adat Kajang yang dikenal dengan istilah Patuntung yang bersumber dari kepercayaan leluhur bercirikan animisme dan dinamisme. Pada awalnya sistem kepercayaan Patuntung adalah sebuah agama adat, berasal dari kata tuntungi berarti sumber kebenaran. Kepercayaan Patuntung pada dasarnya memiliki keyakinan dan pandangan tentang Tuhan (Turi'e A'ra'na), alam dan manusia. Dalam praktiknya, ajaran Patuntung yang mengkiblatkan diri pada Pasang ri Kajang yaitu pesan-pesan, firman, wasiat, amanat dari Sang Pencipta. Seluruh interaksi dalam kehidupan komunitas adat Kajang mengharuskan pola hidup yang sederhana (tallasa kamase-masea), menghindari sikap berlebih-lebihan, memperlakukan makhluk-makhluk di sekelilingnya dengan bersahaja, dan apa adanya. Isi Pasang ri Kajang merupakan himpunan dari sejumlah sistem kehidupan, meliputi sistem kepercayaan, sistem ritus dan sejumlah norma sosial, yang sarat dengan pesan-pesan moral yang luhur dan ajaran-ajaran kebijaksanaan. Tujuan penelitian ini untuk mengungkapkan sistem kepercayaan komunitas adat Kajang yang tertuang dalam Pasang. Penelitian ini dilaksanakan di Desa Tanah Towa, Kabupaten Bulukumba, Provinsi Sulawesi-Selatan. Penelitian ini menggunakan metode kualitatifdeskriptif. Pengumpulan data dilakukan melalui teknik pengamatan dan wawancara kepada beberapa tokoh masyarakat dan warga komunitas adat.
\end{abstract}

Kata kunci : Kepercayaan, Pasang, Turi' e Ara'na, Patuntung. 


\begin{abstract}
This paper describes the belief system of indigenous peoples of Kajang known as Patuntung which is derived from ancestral beliefs characterized by animism and dynamism. At first Patuntung belief system is an indigenous religion, derived from the word tuntungi which means source of truth. Belief system of Patuntung basically has a belief and view of God (Turi'e A'ra'na), mother nature and humankind. In practice the teachings of Patuntung direct itself to Pasang ri Kajang namely messages and words from the Creator. The whole interaction in the lives of indigenous community of Kajang requires a simple lifestyle (tallasa kamase-masea), avoiding exaggerated attitude, and being gentle to every creature around him. The contents of Pasang ri Kajang are a set of living systems, including the system of beliefs, rites and a system of social norms, which are laden with messages of morality and wisdom teachings. The purpose of this study is to reveal the belief systems of indigenous community of Kajang that is contained in the Pasang. This research was conducted in the village of Tanah Towa, Bulukumba, the Province of South Sulawesi. The author conducted a qualitative-descriptive method. Data were collected through observation and interview to several community leaders and the members of the community as well.
\end{abstract}

Keywords: belief, Pasang, Turi' e Ara'na, Patuntung.

\section{A. Pendahuluan}

Indonesia yang terdiri dari puluhan ribu pulau dan ratusan suku bangsa, merupakan sebuah negara dengan heterogenitas tertinggi di muka bumi, yang memiliki keragaman budaya yang mencerminkan kekayaan bangsa yang luar biasa. Salah satu warisan budaya leluhur bangsa Indonesia yang penuh dengan kandungan nilai-nilai luhur, seperti yang terdapat pada sistem kepercayaan yang dianut oleh masyarakatnya. Kepercayaan tersebut dapat berupa kepercayaan terhadap Tuhan Yang Maha Esa, kepercayaan kepada Dewa-dewa, roh-roh halus, roh leluhur, benda-benda gaib, kekuatan sakti dan sebagainya. Kepercayaan masyarakat itu, sampai kini masih tetap hidup, tumbuh dan berkembang pada sebagian masyarakat Indonesia yang tersebar dari Sabang sampai Merauke.

Kepercayaan masyarakat bukan saja merupakan salah satu akar bagi tumbuh kembangnya kebudayaan yang memberi warna serta ciri kebudayaan setempat, lebih dari itu kepercayaankepercayaan tersebut di dalamnya sarat dengan kearifan-kearifan lokal (local wisdom) yang sangat bermanfaat bagi upaya pembentukan karakter, pekerti, dan jati diri bangsa. Kearifan lokal merupakan kekuatan yang mampu bertahan terhadap unsur-unsur yang datang dari luar, mampu berkembang untuk masa-masa yang akan datang. Kepercayaan masyarakat serta kearifan lokal tersebut dapat tumbuh, hidup dan berkembang dalam salah satu lembaga komunitas yang disebut dengan komunitas adat. Perlu disadari dan dipahami bahwa kontribusi kepercayaan masyarakat bagi bangsa Indonesia jelas tidak sedikit, selain merupakan salah satu akar bagi tumbuh kembangnya kebudayaan Indonesia, juga dapat memberi ciri kebudayaan daerah setempat serta mengandung makna dan nilai yang sangat bermanfaat bagi kehidupan manusia, karena di dalamnya terdapat kearifan-kearifan lokal yang perlu dilestarikan.

Kelompok sosial atau disebut komunitas adat pada umumnya lahir, tumbuh dan berkembang tidak berada 
pada koridor menjalankan syariat agama yang disyaratkan sebagai Warga Negara Indonesia (WNI), tetapi justru komunitas adat dimaksud itu, meskipun secara administrasi mencantumkan salah satu agama Tuhan dalam kartu identitasnya (KTP), namun hal semacam ini hanyalah merupakan lambang belaka, seperti halnya komunitas adat Kajang yang terdapat di Desa Tanah Towa Kabupaten Bulukumba yang sekaligus dijadikan sebagai objek kajian dalam tulisan ini. Kelompok sosial ini berkembang dan tumbuh dengan menganut nama aliran yang disebut aliran kepercayaan Patuntung. Aliran kepercayaan ini, dapat ditempatkan sebagai salah satu aspek atau komponen dari agama atau religi. Koentjaraningrat (1984), memandang agama itu sebagai suatu sistem yang disebutnya sebagai "sistem religi" yang esensinya terdiri atas empat komponen yaitu: (1) Keagamaan yang menyebabkan manusia memiliki rasa dan semangat beragama. (2) Sistem kepercaayaan atau sistem keyakinan yang mencakup segala keyakinan terutama terhadap Tuhan dan kehidupan gaib, termasuk sistem nilai dan norma moral. (3) Sistem ritus' sebagai upaya manusia mengadakan hubungan dan melakukan pendekatan kepada Tuhan dan sikapnya menghadapi lingkungannya. (4) Solidaritas sosial atau sistem sosial. Dari ke empat komponen tersebut, ada tiga komponen yang dijadikan acuan dalam menganalisis sistem religi komunitas adat Kajang, yaitu sistem kepercayaan/keyakinan, sistem ritus dan solidaritas sosial.

Sehubungan dengan hal tersebut di atas, penelitian ini menjadi penting untuk dilakukan secara sistematis guna mengkaji mengenai "Sistem Kepercayaan Komunitas Adat Kajang," yang merupakan khazanah budaya bangsa dan menjadi pembentukan karakter dan jatidiri bangsa. Dalam kondisi yang demikian, maka perumusan masalah dalam tulisan ini, akan mencoba memfokuskan pada permasalahan yang terungkap lewat pertanyaan, yakni "Bagaimana bentuk kepercayaan dan pelaksanaan upacara ritual yang dijalankan oleh komunitas adat Kajang." Adapun tujuan pelaksanaan penelitian ini pada intinya adalah menjawab dari permasalahan yang terungkap dalam rumusan masalah, dalam hal ini untuk memberi gambaran secara utuh dan komprehensip mengenai bentuk kepercayaan dan upacara yang dijalankan oleh komunitas adat Kajang. Hasil penelitian ini diharapkan akan dapat memberikan informasi atau masukan bagi pihak-pihak yang berkepentingan demi terpeliharanya kelestarian nilai-nilai budaya dalam kepercayaan komunitas adat umumnya, khususnya pada komunitas adat Kajang di Desa Tanah Towa, Kabupaten Bulukumba. Disamping itu, juga dapat memberikan bahan refrensi bagi peneliti, ilmuawan serta semua pihak yang ingin mengkaji atau meneliti tentang kepercayaan komunitas adat Kajang untuk dapat mengembangkan pada penelitian selanjutnya.

Kemudian ruang lingkup penelitiannya meliputi dua hal, yakni ruang lingkup wilayah dan materi. Ruang lingkup wilayah penelitian ini adalah Desa Tanah Towa, Kecamatan Kajang, Kabupaten Bulukumba. Desa Tanah Towa ini dipilih sebagai lokasi penelitian karena pertimbangan bahwa di desa tersebut merupakan wilayah adat yang didiami oleh sekelompok masyarakat yang mengidentifikasi diri sebagai komunitas adat Kajang. Selain itu, hingga saat ini masih memelihara nilai-nilai luhur dan melaksanakan tradisi warisan nenek moyang mereka, salah satu diantaranya adalah ritualritual yang berkaitan dengan kehidupan mereka. Sedangkan ruang lingkup materi, yaitu berbagai hal yang menyangkut kepercayaan melalui upacara atau ritual-ritual. 
Penelitian ini merupakan jenis penelitian bersifat deskriptif yang menggambarkan secara tepat sifat-sifat suatu gejala sosial, baik individuindividu, kelompok-kelompok dan keadaan sosial tertentu. Oleh karena itu, pendekatan atau metode yang dipandang tepat untuk jenis penelitian deskriptif ini adalah pendekatan kualitatif, yakni untuk menangkap berbagai gejala yang diperoleh melalui pengalaman dari para informan. Selain itu, juga dilakukan pengamatan atau observasi terhadap tingkah laku komunitas. Dengan demikian, maka alat yang digunakan untuk memperoleh informasi dan keterangan adalah melalui wawancara yang mendalam dengan informasi yang terpilih. Data dan informasi yang diperoleh dianalisis secara kualitatif, kemudian dideskripsikan serta disusun sesuai dengan kerangka laporan yang telah ditetapkan.

Dalam mengkaji permasalahan pada penelitian ini, kiranya perlu terlebih dahulu dijelaskan beberapa konsep atau pengertian oleh para ilmuawan yang terdapat di dalamnya, guna menjadi acuan atau kerangka pemikiran untuk kepentingan operasional. Konsep atau pengertian yang dimaksud dalam penelitian ini, adalah konsep tentang kepercayaan dan komunitas adat. Kepercayaan adalah sebutan bagi sistem religi yang tidak termasuk salah satu dari agama-agama yang diakui pemerintah (Islam, Kristen, Katolik, Hindu dan Budha). Menurut I Made Suarsana (2012: 8) bahwa kepercayaan adalah sistem tingkah laku manusia untuk mencapai suatu maksud tertentu dengan cara menyandarkan diri pada kemauan dan kekuasaan makhluk seperti roh, dewa, dan sebagainya. Semua sistem kepercayaan tersebut berpusat pada konsep tentang hal yang gaib, maha dahsyat dan keramat. Selanjutnya, H.P. Badrum (1985), dijelaskan bahwa dari berbagai pembahasan tentang agama atau religi, pada umumnya menempatkan "sistem kepercayaan" itu sebagai salah satu aspek atau komponen dari agama atau relig.

Koentjaraningrat (1984: 5) memandang agama itu sebagai suatu sistem yang disebutnya sebagai "sistem religi" yang esensinya terdiri atas empat komponen yaitu (1) Emosi keagamaan yang menyebabkan manusia memilki rasa dan semangat beragama; (2) Sistem kepercayaan atau sistem keyakinan mencakup segala keyakinan terutama terhadap Tuhan dan kehidupan gaib, termasuk sistem nilai dan norma moral; (3) Sistem ritus sebagai upaya manusia mengadakan hubungan dan melakukan pendekatan kepada Tuhan dan sikapnya menghadapi lingkungan; (4) Solidaritas sosial atau sistem sosial. Sementara itu, Glock dan Stark (1966) membagi agama itu atas lima aspek atau dimensi yaitu: (1) Dimensi keyakinan; (2) Dimensi peribadatan; (3) Dimensi penghayatan; (4) Dimensi pengalaman; dan (5) Dimensi pengetahuan. Kemudian ajaran Islam itu sendiri, menurut hadits Umar, r. a. bahwa agama itu terbagi atas tiga aspek yaitu iman, islam, dan ihsan.

Dari berbagai pembagian tentang agama yang dikemukakan di atas, tampak dengan jelas bahwa sistem kepercayaan atau keyakinan hanya merupakan salah satu aspek atau komponen dari agama. Sementara fenomena keberagamaan suatu masyarakat atau komunitas tidak bisa dipahami secara utuh manakala hanya dilihat dari aspek sistem kepercayaan semata. Oleh karenanya, pembahasan tentang "Sistem Kepercayaan, akan lebih diperluas menjadi "Sistem Religi". Menurut Koentjaraningrat (1991: 295), unsur terpenting dari religi adalah adanya kepercayaan manusia tentang sesuatu kekuatan gaib di luar dari kekuatan manusia. Oleh karena itu, manusia melakukan berbagai macam aktivitas untuk berkomunikasi atau 
berhubungan dengan kekuatan gaib tersebut. Kemudian semua aktivitas manusia yang berkaitan dengan religi berdasarkan getaran jiwa atau disebut emosi keagamaan (religious emotion). Emosi keagamaan menyebabkan suatu benda dan tindakan atau gagasan mendapat nilai keramat (secred volue).

Selanjutnya, konsep komunitas adat atau sering juga disebut dengan istilah masyarakat adat, yang merupakan istilah umum untuk dipakai menyebut suatu kelompok masyarakat yang teguh memegang adat istiadat. Menurut Koetjaraningrat (2002: 6-8), bahwa komunitas (community) dapat pula diterjemahkan sebagai "masyarakat setempat", yakni merupakan kesatuan sosial yang lebih didasarkan oleh rasa kesadaran wilayah tertentu atau pada ikatan daerah tempat tinggal. Sebagai suatu kesatuan sosial, warga dalam komunitas mempunyai sifat adanya rasa kesamaan dan kebersamaan. Perasaan kesamaan dan kebersamaan dalam komunitas biasanya sangat kuat, sehingga ada perasaan bahwa kelompoknya itu memiliki ciri-ciri kebudayaan atau cara hidup yang berbeda dari kelompok lainnya. Lanjut Koentjaraningrat (1991: 25), mengemukakan bahwa komunitas adat merupakan suatu kesatuan hidup manusia yang menempati suatu wilayah yang nyata, dan yang berinteraksi menurut suatu sistem adat istiadat serta yang terkait oleh suatu rasa identitas komunitas.

Menurut Taneko (1984), komunitas adat merupakan suatu kelompok sosial yang dapat dinyatakan sebagai masyarakat setempat, suatu kelompok yang betempat tinggal dalam suatu wilayah tertentu dalam batas-batas tertentu pula dan dapat memenuhi kebutuhan hidupnya, dilingkupi oleh perasaan kelompok yang kuat diantara anggotanya. Sementara Bustamin (2011) dalam sebuah makalanya yang berjudul "Teknik Inventarisasi Kepercayaan
Komunitas Adat," menyatakan bahwa komunitas adat itu adalah sebagai suatu kelompok masyarakat yang bertempat tinggal di suatu wilayah, yang memiliki kesamaan identitas budaya, kesamaan asal usul, kesamaan pengetahuan yang digunakan bersama dalam mengelolah dan memanfaatkan lingkungan hidupnya secara turun-temurun dan memiliki aturan adat, tata kelembagaan dalam pemenuhan kebutuhan hidup yang diekspresikan dalam kehidupan mereka sehingga menjadi jati diri yang spesifik. Konsep-konsep inilah yang akan dipakai dasar dan acuan dalam membahas permasalahan yang ada serta dalam mendeskripsikannya menjadi sebuah tulisan.

\section{B.HASIL DAN BAHASAN}

\section{Profil Desa Tanah Towa}

\section{a. Lokasi dan keadaan geografis}

Desa Tanah Towa terletak di sebelah utara dalam wilayah Kecamatan Kajang Kabupaten Bulukumba, Provinsi Sulawesi Selatan. Desa Tanah Towa merupakan lokasi bermukimnya sekelompok masyarakat yang mengidentifikasi diri sebagai komunitas adat yang populer dengan nama Komunitas adat Kajang, yang memiliki pemimpin adat atau disebut dengan istilah Ammatoa. Tanah Towa merupakan sebagai sebuah wilayah administrasi setingkat desa/kelurahan, dan pada prinsipnya tumbuh dan terbangun dengan dua kelompok masyarakat yang boleh dikatakan berbeda dengan satu sama lainnya dalam banyak hal, terutama perbedaan yang paling menonjol adalah persoalan dalam pandangan hidup, yaitu satu kelompok masyarakat yang memang berpegang teguh pada agama Islam sebagai pedoman dalam berkehidupan, dan satu kelompok masyarakat lainnya adalah kelompok orang-orang yang menamakan dirinya penganut aliran kepercayaan patuntung atau sering juga masyarakat dimaksud disebut 
masyarakat penganut aliran kepercayaan Kajang.

Kedua kelompok masyarakat Kajang menempati dua wilayah hunian yang diberi nama Ilalang Embaya dan Ipantarang Embaya. Istilah IIalang berarti di dalam, embaya artinya wilayah kekuasaan, jadi Ilalang Embaya berarti di dalam wilayah kekuasaan adat. Ipantarang artinya di luar, jadi Ipantara Embaya berarti di luar kawasan adat, atau tidak masuk dalam zona kawasan adat. Ilalang Embaya dapat dipahami sebagai wilayah yang berada dalam kekuasaan Ammatoa (ketua adat). Sebaliknya Ipantarang Embaya bermakna wilayah yang berada di luar kekuasaan Ammatoa, wilayah itu dibawa pengawasan pemerintahan struktur administrasi desa. Kedua wilayah kawasan itu dibatasi oleh bangunan pintu gerbang untuk memasuki kawasan adat (Ilalang Embayya), seperti tampak pada gambar di bawah ini:

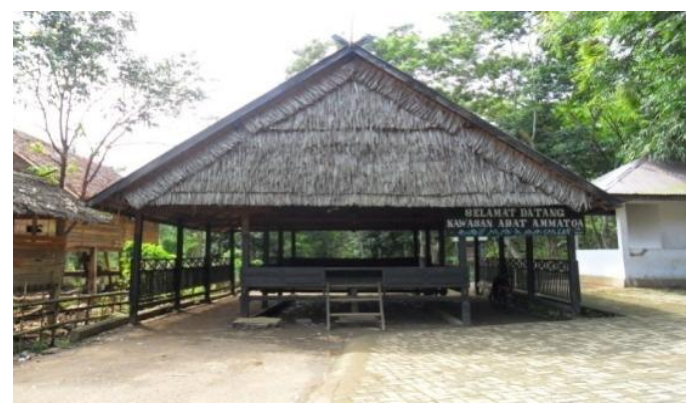

Gambar 1.

\section{Embaya}

Pintu gerbang kawasan Ilalang

Wilayah Desa Tanah Towa terdiri atas 9 (sembilan) dusun dan kesembilan buah dusun yang ada diantaranya masuk dalam kawasan adat (Ilalang Embayya), yaitu Dusun Balagana, Jannayya, Sobba, Benteng, Pangi, Bongkina, Tombolo, Lurayya dan Dusun Balambi. Sementara dua dusun lainnya berada di luar kawasan adat (Ipantarang Embayya). Desa Tanah Towa yang tersebar atas sembilan dusun itu, dihuni penduduk sebanyak 4.073 jiwa, terdiri dari laki- laki 1.904 jiwa dan perempuan 2.169 jiwa. Dari jumlah keseluruhan penduduk Tanah Towa, 3.208 orang menempati wilayah kawasan adat, sedangkan sisanya yaitu 865 orang bermukim di luar kawasan adat.

Secara geografis wilayah pemukiman penduduk berada pada ketinggian 150-500 meter di atas permukaan laut. Pada radius ketinggian seperti itu, menyebabkan udara di kawasan Kajang sangat sejuk. Suhu udara rata-rata di wilayah tersebut berada pada kisaran $13-29$ derajat celcius, dengan kelembaban udara $70 \%$. Sementara itu curah hujan setiap tahunnya adalah 5745 milimeter. Kondisi alam seperti ini, menyebabkan berbagai macam tanaman pertanian dan perkebunan dapat tumbuh serta hutan yang subur dan lebat yang menghasilkan berbagai jenis kayu. Luas wilayah Desa Tanah Towa secara keseluruhan tercatat 972 hektar dengan berbagai penggunaannya, yaitu 169 hektar untuk tanah pemukiman, 93 hektar untuk persawahan, 30 hektar untuk perkebunan, 5 hektar untuk kuburan, 95 hektar untuk pekarangan, 1 hektar untuk perkantoran, 5 hektar untuk prasarana umum, dan untuk areal hutan adalah lebih kurang 331 hektar.

Secara administrasi, Desa Tanah Towa berbatasan yaitu sebelah utara Desa Batunilamung, sebelah selatan dengan Desa Bontobaji, sebelah timur dengan Desa Malleleng, dan sebelah barat dengan Desa Pattiroang. Jarak tempuh dari Desa Tanah Towa ke ibukota Kecamatan Kajang \pm 25 kilometer, dari ibukota Kabupaten Bulukumba \pm 57 kilometer dan dari kota Makassar \pm 270 kilometer. Kondisi jalan dari kesemua akses cukup baik sehingga jarak tempuh ke lokasi tersebut yang lebih mudah.

\section{b. Pola Pemukiman}

Pola pemukiman penduduk di dalam kawasan adat (Ilalang Embayya) 
hingga saat ini masih mempertahankan pola lama, terkait dengan sistem kepercayaan mereka yang masih kokoh. Pola pemukiman penduduk berkelompok setiap dusun, dengan bentuk rumah seragam. Arah bangunan rumah di kawasan Ilalang Embaya selalu menyamping dari kawasan borong karama' (hutan keramat) yang sangat dilindungi dan dijaga kelestariannya oleh masyarakat setempat, sehingga semua rumah menghadap ke Barat dan tertata rapi serta berjejer dari utara ke selatan. Sebagai pembatas antara pemukiman penduduk dengan hutan keramat dibuat pagar yang tersusun dari batu kali setinggi satu meter. Pagar ini dibuat untuk menghindari pandangan ke arah borong karamaka, hal tersebut dianggap tabu (kasipalli) kalau menghadap ke arah hutan borong karama.' Ketentuan ini dimaksudkan agar penghuni rumah tidak dapat melihat begitu banyak potensi hasil hutan, yang dapat dimanfaatkan, sehingga tergiur untuk mengambilnya yang dapat berakibat merusak hutan. Selain itu, faktor kondisi pemukiman dimana setiap rumah terletak di tengahtengah kebun keluarga, juga karena penataan itu harus dengan prinsip dari Pasang (aturan tak tertulis yang menjadi petunjuk atau pedoman dalam kehidupan masyarakat adat Kajang).

Keunikan rumah penduduk dalam kawasan adat, yang berbentuk rumah panggung, tidak menggunakan bahan atau material dari industri modern. Ketika kita naik ke rumah, maka yang pertama didapati adalah dapur berdekatan dengan pintu masuk, lalu ruang tengah dan bilik bagian belakang adalah ruang tamu. Selain itu, posisi rumah yang semuanya menghadap ke arah barat tempat terbenamnya matahari. Maknanya adalah bahwa semua kehidupan ini akan berakhir, sama dengan tenggelamnya matahari dalam kegelapan malam.
Kawasan adat Kajang luar (Ipantarang Embayya) telah membentuk pemukiman tersendiri, yang berbeda dengan pola pemukiman masyarakat dalam (Ilalang Embaya). Perbedaan tersebut terlihat pada penataan letak bangunan rumah dan arah rumah. Pada masa lalu, semuanya memiliki penataan dan arah rumah yang sama, yaitu menghadap ke barat, berhadapan dengan gunung Bawakaraeng (gunung yang dikeramatkan dan disucikan yang ada di daerah Sulawesi Selatan). Arah tersebut diyakini dapat memberikan rahmat dan keselamatan bagi penghuni rumah, karena tempat bersemayamnya Dewa Patanna Lino (Dewa pemilik bumi). Seiring dengan perkembangan zaman, kepercayaan yang berkaitan arah rumah mengalami perubahan terutama bagi penduduk yang berada di luar kawasan adat. Hal ini dikondisikan dengan prasarana jalan yang dibangun pemerintah, menyebabkan arah bangunan rumah sudah menghadap ke jalan, tidak lagi menghadap ke arah barat sesuai kepercayaan leluhurnya. Bentuk arsitektur bangunan rumah telah banyak mencontoh model bangunan suku Bugis dan Makassar yang bermukim di Bulukumba, yang sudah menggunakan atap seng, dinding rumah sudah dapat dicat dan menggunakan ventilasi yang terbuat dari kaca. Tiangtiang rumah diberi penyangga yang terbuat dari batu atau cor baton, dan sebagian pula rumah penduduk sudah permanen atau semi permanen.

\section{c. Agama dan Kepercayaan}

Masyarakat adat Kajang termasuk yang bermukim di kawasan Ilalang Embayya menganut agama Islam, seperti yang nampak pada Kartu Tanda Pengenal (KTP), walaupun dalam implementasinya mereka tidak melaksanakan sesuai dengan syariat Islam seperti shalat, zakat, puasa dan haji. Namun komitmen mereka terhadap agama Islam cukup kuat walaupun 
sebatas pengakuan, dan belum menyentuh kehidupan keseharian mereka. Menurut pengakuan Ammatoa serta pembantu-pembantunya, bahwa mereka mengakui Islam sebagai agamanya, tetapi praktek amaliahnya sedikit berbeda dengan syariat ajaran Islam sebagaimana yang dipahami oleh masyarakat Islam di Indonesia. Walaupun kesehariannya mereka penganut kepercayaan Patuntun, tetapi mereka tidak mau disebut penganut agama Patuntung, menurutnya patuntung bukan agama melainkan kepercayaan yang wajib dipatuhi dan dilaksanakan oleh setiap anggota masyarakat adat Kajang, sebagai "penuntut" atau "penuntun" untuk mengamalkan ajaran kebenaran yang diwasiatkan secara lisan oleh para leluhur mereka secara turun-temurun dari generasi ke generasi, mulai yang pertama sampai yang terakhir. Wasiat inilah yang dikenal dengan sebutan Pasang atau Pasang ri Kajang.

Pasang ri Kajang adalah ajaran leluhur masyarakat Kajang. Secara harfiah Pasang dapat berarti pesanpesan, firman, wasiat, amanat. Pasang dapat pula dikatakan sebagai wahyu dari Tuhan Yang Maha Esa kepada ummatnya dengan harapan manusia dapat menjalani kehidupan dengan baik mengikuti rambu-rambu yang diinginkan oleh Sang Pencipta. Sebagai pedoman yang paling tinggi, Pasang menjadi referensi yang dijadikan acuan. Semua yang tertera dalam Pasang membentuk pola berpikir dan cara-cara bertindak komunitas adat ini, sebagaimana dikatakan oleh Usop (1978), bahwa Pasang berarti pesan lisan yang wajib dituruti, dipatuhi dan dilaksanakan, dan apabila tidak diindahkan akan menimbulkan hal-hal atau akibat-akibat yang tidak diinginkan. Ia mengandung arti pesan, amanah, nasihat, tuntutan, peringatan atau pengingatan. Dari pengertian inilah masyarakat adat Kajang berpegang pada
Pasang. Ia tidak hanya berisi yang baik yang harus diamalkan, akan tetapi juga yang buruk yang harus dijauhi. Dalam kondisi demikian, nampak bahwa Pasang ri Kajang merupakan himpunan dari sejumlah sistem kehidupan, yang meliputi sistem kepercayaan, sistem ritus dan sejumlah norma sosial lainnya.

Aturan-aturan dalam Pasang masih diberlakukan secara ketat oleh masyarakat di kawasan Ilalang Embaya, terutama pada kegiatan ritual atau upacara adat, misalnya pada upacara Apparuntuk paknganro, yaitu upacara memohon doa atau mengucap syukur kepada Turi'e A'ra'na, baik yang bersifat umum yang diselenggarakan oleh Ammatoa, maupun yang khusus diselenggarakan oleh warga masyarakat adat tertentu berdasarkan hajat mereka. Pelaksanaan Pasang pada masyarakat Kajang yang bermukim di luar kawasan Ipantarang Embaya tidaklah seketat yang ada di dalam kawasan, karena mereka telah beradaptasi dan berbaur dengan masyarakat yang telah menggunakan teknologi modern.

Dari segi kepercayaan masyarakat Kajang memiliki dualisme kepercayaan, yakni Islam sebagai agama yang diakui negara dan kepercayaan Patuntung sebagai ajaran leluhur yang wajib dijalankan. Pemahaman ajaran agama Islam di kalangan mereka tidak didasarkan pada pemahaman syariat Islam, akan tetapi didasarkan pada kegiatan yang berkaitan dengan tarekat. Hal ini di pahami karena di kalangan warga masyarakat adat Kajang di Desa Tanah Towa pada waktu itu, tidak ada yang bisa baca tulis sehingga usaha untuk menimba ilmu tentang agama mengalami kesulitan. Salah satu wujud pemahaman warga masyarakat adat Kajang khususnya yang berdomisili kawasan IIalalang Embayya yang ada kaitannya dengan tarekat, adalah mengamalkan jenne talluka, sembahyang tamattappuka, artinya wudhu yang tidak pernah batal, dan 
shalat yang tidak pernah terputus. Dari ungkapan ini dapat dipahami bahwa dengan berbuat amal kepada sesama manusia, berarti sudah melaksanakan shalat, dan kegiatan keagamaan lainnya sesuai dengan syariat Islam.

\section{d. Pola Hidup dan Tradisi}

Masyarakat adat Kajang adalah sebuah komunitas klasik yang masih kental akan adat istiadatnya dan tradisi. Mereka ini hidup berkelompok dalam suatu area hutan, dan menjauhkan diri dari segala sesuatu yang berhubungan dengan hal-hal modernisasi. Hal ini disebabkan oleh adanya hubungan masyarakat adat dengan lingkungan hutannya yang selalu bersandar pada pandangan hidup adat yang mereka yakini. Dalam hal-hal tertentu mereka berinteraksi dengan pola komunikasi dengan unik. Ketika akan menyampaikan pengumuman atau informasi ke masyarakat, mereka melakukan menabuh gendang yang disebut benrong. Gendang ini dibunyikan atau ditabuh dalam kondisi tertentu; seperti saat ada kematian, ada pencurian atau peristiwa lainnya. Cara penabuhan gendang ini berbeda-beda, disesuaikan dengan peristiwa yang terjadi dan mereka sendirilah yang memahami arti setiap jenis bunyi gendang tersebut.

Pola hidup sederhana yang disebut tallasa kamase-kamasea, merupakan prinsip hidup komunitas adat Kajang. Kesederhanan adalah salah satu ciri utama yang menekankan orientasi hidup saling rukun dalam satu rumpun, saling berbagi, tidak menjatuhkan satu sama lain, menghindari sikap hidup berlebihlebihan dan hidup apa adanya, serta memperlakukan mahluk-mahluk di sekelilingnya dengan bersahaja. Kehidupan masyarakat adat Kajang dengan penuh kesederhanaan tanpa memikirkan hidup mewah, akan membawa makna tersendiri di tengah kehidupan masyarakat modern.
Konsep hidup kamase-masea sebagai sesuatu yang telah ditetapkan oleh Turi'e A'ra'na, dan sebagai tau todong (lemah/prihatin). Kedua konsep tersebut bertentangan dengan hidup kalumannyang (kaya). Sesuai dengan takdirnya (turunganna) mereka tidak layak hidup kaya, karena sejak nenek moyang mereka sudah ditakdirkan atau diharuskan untuk hidup sederhana. Seperti diungkapkan dalam Pasang: "Dodongi kamase-masea, hujui rikalenna, anre nakulle kaite-ite, Anre nakulle katoli-toli Kasugihanga anre nakulle antama ri butta kamase-masea." Artinya meski kita serba susah dalam kesederhanaan, tetap berpegang pada prinsip sendiri, tidak boleh sembarang melihat, tidak boleh sembarang melompat, tidak boleh sembarang mendengar, kekayaan tidak akan pernah masuk di kawasan adat.

Prinsip Tallasa kamase-masea, juga berarti tidak mempunyai keinginan yang berlebih-lebihan dalam kehidupan sehari-hari, baik untuk makan maupun dalam berpakaian. Dalam berpakaian yang memiliki hanya 2 (dua) warna yakni hitam dan putih. Untuk baju, sarung dan penutup kepala berwarna hitam dan celana berwarnah putih. Menurut mereka berpakaian dengan beragam warna, menandakan kemewahan warna tersebut tidak lepas dari makna spiritualitas dalam kehidupan masyarakat adat Kajang, yang memandang bahwa manusia berasal dari kegelapan dan terlahir ke dunia dengan cahaya yang terang benderang, serta wujud dari pada kesamaan dalam segala hal, termasuk kesamaan dalam kesederhanaan, tidak ada warna hitam yang lebih baik antara yang satu dengan yang lainnya. Semua warna hitam di dalam kawasan adat adalah sama, warna hitam menunjukkan kekuatan, kesamaan derajat bagi setiap orang di depan Sang Pencipta (Turi'e A'ra'na). 
Peralatan rumah yang dimiliki
masih menggunakan peralatan
sederhana yang dibuat sendiri, seperti
tempat duduk dan tidur mereka
menggunakan tikar, begitu juga
peralatan makan dan minum serta
peralatan pertanian masih tetap
menggunakan peralatan sederhana. Ketika kita naik ke rumah, maka yang pertama didapati adalah dapur yang dekat dengan pintu masuk rumah, lalu ruang tengah dan bilik bagian belakang adalah ruang tamu. Selain itu, posisi rumah yang semuanya menghadap ke arah barat tempat terbenamnya matahari. Maknanya adalah bahwa semua kehidupan ini akan berakhir, sama dengan tenggelamnya matahari dalam kegelapan malam.

Dalam kehidupan sehari-hari, masyarakat adat Kajang memegang teguh Pasang ri Kajang (pesan di Kajang) merupakan ajaran leluhur. Secara harfiah Pasang dapat berarti pesan-pesan, firman, wasiat, amanat. Jadi Pasang dapat dikatakan sebagai wahyu dari Tuhan Yang Maha Esa kepada ummatnya dengan harapan manusia dapat menjalani kehidupan dengan baik mengikuti rambu-rambu yang diinginkan oleh Sang Pencipta.

Penerapan aturan atau hukumhukum di dalam komunitas adat Kajang ini, juga masih memegang prinsipprinsip hukum yang diwariskan nenek moyang atau para pendahulunya. Apalagi terjadi pelanggaran adat dalam kawasan, hukum yang berlaku dalam masyarakat adat Kajang disebut $B a^{\prime}$ 'bala (cambuk). Beratnya hukuman didasarkan pada pelanggaaran yang dilakukan oleh seseorang yang terbukti sebagai terdakwa. Dalam hal ini terbagi atas tiga jenis kategori hukum : yaitu Cappa'Ba'bala, Tangnga Ba'bala, dan Poko' Ba'bala.

Istilah Cappa' Ba'bala (ujung cambuk), dimana jenis hukuman ini sifatnya ringan. Selanjutnya, Tangnga $B a$ 'bala (bagian tengah cambuk), jenis hukuman ini sifatnya sedang. Yang terakhir adalah Poko' Ba 'bala (pangkal cambuk), jenis hukuman ini tergolong berat. Dalam pengkategorian jenis-jenis hukuman tersebut, tentunya berdasarkan kesepakatan adat dan ketentuanketentuan dalam Pasang.

\section{Sistem Kepercayaan}

Sistem kepercayaan atau religi pada prinsipnya terdiri atas konsepkonsep yang menimbulkan keyakinan dan ketaatan bagi penganutnya. Keyakinan itu adalah rasa percaya akan adanya dunia gaib, ide tentang "Tuhan," hari kemudian, percaya akan adanya kekuatan-kekuatan supranatural, serta berbagai macam hal yang dapat menimbulkan rasa percaya kepada yang diyakini (Akip, 2008 : 48). Berdasarkan pandangan tersebut, komunitas adat Kajang pada dasarnya lahir, tumbuh dan berkembang tidak menjadikan agama Tuhan sebagai tuntunan dalam hidup. Mereka mengacu pada tuntunan sebuah aliran kepercayaan Patuntung, dan meyakini Turi'e A'ra'na sebagai Tuhan pencipta alam semesta beserta isinya. Dalam kehidupan komunitas adat Kajang, selain melakukan penyembahan terhadap Tuhan yang diakuinya, juga mereka tetap berkiblat pada sang pemimpin ummat, yaitu kepada Ammatoa dan sekaligus pula sebagai kepala pemerintahan adat. Pada dasarnya apa yang mereka perbuat dalam keberadaannya sebagai penganut aliran kepercayaan, dijalankannya sebagai sebuah amanah dari para leluhurnya yang mereka junjung tinggi yaitu Pasang ri Kajang, yang telah disesuaikan dengan pokok-pokok ajaran agama Islam.

Salah satu karakteristik pada masyarakat adat Kajang dewasa ini yang masih eksis dengan melakukan berbagai ragam upacara atau ritual dalam kepercayaan mereka, yakni dengan melihat hutan itu sebagai bagian dari 
hidupnya. Eksistensi ritual kuno ini telah melampaui batas-batas zaman dan menjadi salah satu bagian penting dari representasi dari masyarakat adat Kajang itu sendiri. Upacara atau ritual secara umum dipahami sebagai ekspresi keagamaan dalam wujud perilaku yang dijadikan sebagai media untuk berkomunikasi dengan hal-hal yang gaib. Dalam tataran implementasi atau praktik ritual tersebut, tampil beragam berdasarkan kepercayaan masingmasing sekaligus merupakan karakteristik budaya komunitas tertentu. Dalam hubungannya upacara atau perayaan keagamaan, upacara merupakan sarana untuk menghubungkan antara manusia dengan hal-hal keramat yang diwujudkan dalam praktek (Haviland, 1999: 207). Oleh karena itu, upacara bukan hanya sarana untuk memperkuat ikatan sosial kelompok dan mengurangi ketegangan, tetapi juga suatu cara untuk merayakan peristiwa-peristiwa penting. Ritual keagamaan sebagai bentuk suatu keyakinan manusia terhadap sesuatu yang dapat menyertai manusia dalam ruang lingkup kehidupan, memiliki nilai dan norma yang mengatur kehidupan manusia dalam hubungannya dengan masyarakat. Ritual bagi komunitas adat Kajang dijadikan sebagai dasar atau etika sosial di mana praktik sosial digerakkan.

Masyarakat adat Kajang menempatkan ritual dan seremoni itu sebagai bagian yang penting dalam sistem kehidupan dan interaksi sosial masyarakat, hampir seluruh aspek kehidupan masyarakat adat Kajang mengindikasikan perlunya individu untuk melakukan interaksi dan integrasi dengan masyarakat lainnya. Ritual sebagai manifestasi dari sistem kepercayaan masyarakat adat Kajang yang mengandung kearifan lokal yang signifikan untuk dilestarikan sebagai bagian penting dari proses pembangunan mentalitas dan ketahanan budaya bangsa, termasuk pembangunan karakter dan jatidiri bangsa. Salah satu instrumen penting dalam rangka melestarikan nilai kearifan lokal adalah melakukan kajian penelitian secara sistematis tentang ritual dan kepercayaan masyarakat pada komunitas adat. Memahami ritual dan kepercayaan dalam suatu komunitas adat dapat menjadi pembelajaran dengan melihat aspek filosofis, sosiologis, antropologis dan ekologis pada suatu komunitas adat tertentu.

Studi mengenai ritual yang dijalankan oleh masyarakat yang menganut sistem kepercayaan Patuntung, sejauh penelusuran penulis akan menemukan tiga tulisan yang secara tegas mengkaji, walaupun disana sini terdapat ketertarikan sudut pandang dan penerapan perspektif yang berbeda. Ketiga tulisan tersebut pertama adalah Kepercayaan Patuntung dengan topik Patuntung di Kecamatan Sinjai Barat (Suatu Tinjauan Sosio Kultural) oleh Abdullah Renre (1978), kedua dengan Topik Potret Manusia Kajang, di dalam tulisannya juga secara signifikan menguraikan ritual masyarakat Patuntung (Akip, 2003) dan terakhir adalah oleh Hayat (2006), mengkaji tentang masyarakat Onto yang pada dasarnya juga menganut Sistem Kepercayaan Patuntung. Dari ketiga tulisan tersebut terdapat adanya dua sistem kepercayaan yang diyakini dan dijalankan oleh masyarakat adat Kajang. Kedua keyakinan itu pada suatu masyarakat yakni masyarakat Sinjai Barat yang diistilahkan dengan dualisme; yakni Islam sebagai suatu agama yang dianggap benar di satu pihak, dan kepercayaan Patuntung sebagai suatu sistem kepercayaan masyarakat yang diwarisi dari nenek moyang mereka di pihak lain.

Berdasarkan informasi baik sifatnya lisan maupun tertulis, bahwa pada awalnya (sebelum masuknya Islam) sistem kepercayaan yang dianut oleh masyarakat adat Kajang sebagai 
sebuah agama adat, disebut dengan istilah Patuntung. Istilah Patuntung ini berasal dari kata tuntungi (bahasa Makassar) dan jika diterjemahkan ke dalam bahasa Indonesia berarti "mencari sumber kebenaran" (to inguiri into or to investigate the truth). Namun dalam perkembangannya, setelah kerajaan Gowa dan Bone menerima Islam sebagai agama resmi pada abad ke-17, dengan melalui Janggo Toa kemudian disusul Tu Jarra dan Asara Dg. Mallipa pada waktu itu, sehingga secara bertahap Islam dikenalkan oleh komunitas adat Kajang (Akip, 2008 : 42). Dalam kondisi yang demikian, maka kepercayaan Patuntung yang hidup dan tumbuh dalam wilayah Kajang dalam (Tana to kamse-masea) bukan lagi budaya spiritual tradisional murni, akan tetapi sudah mendapat pengaruh ide spiritual Islam.

Dari beberapa hasil penelitian dijelaskan bahwa sistem kepercayaan Patuntung pada dasarnya relatif sama dengan sistem kepercayaan Patuntung yang diyakini oleh komunitas adat lainnya. Dalam hal ini kepercayaan Patuntung komunitas adat Kajang memiliki pandangan dalam melakoni hidupnya, yaitu pandangan Patuntung dalam mengenal Tuhan, dan pandangan Patuntung dalam mengenal manusia serta alam atau lingkungannya (Renre, 1978; Manda, 2007 dan Akip, 2003)

Pandangan Patuntung dalam mengenal Tuhannya; pada prinsipnya terbagi atas tiga jenis dan masingmasing berpengaruh terhadap hidup dan kehidupan manusia, yaitu (1). Karaeng Ampatana sebagai pencipta alam semesta dan seisinya, tempat tinggalnya diyakini di langit. (2). Karaeng Kaminang Kammaya atau Kaminang Jaria A'ra'na yang diartikan sebagai kuasa atau perkasa, bertempat tinggal di Tombolo Tikka (puncak Gunung Bawakaraeng) yang dikeramatkan dan disucikan, dan (3). Karaeng Patanna Lino atau Patanna Pa'rasangang yang ditugasi memelihara alam ciptaan Ampatana, khusus untuk di bumi termasuk manusia. Selain ketiga Tuhan tersebut dipercayai pula bahwa setiap tempat, tumbuh-tumbuhan dan bendabenda tertentu dihuni oleh kekuatan gaib yang sakti, terutama tempat-tempat yang dianggap keramat. Kekuatan-kekuatan sakti itu dipercayai bersumber dari ketiga Tuhan yang dianggapnya menghuni alam semesta ini.

Pandangan Patuntung tentang Alam; kepercayaan ini melihat alam sebagai suatu kesatuan yang berkaitan antara satu dengan yang lainnya. Bagi masyarakat adat Kajang sangat menggantungkan hidupnya pada lingkungan alam termasuk tanah (sebagai anrongta), hutan adat (sebagai tempat upacara ritus kepercayaan Patuntung). Pandangan Patuntung tentang alam ini, dapat dilihat sebagai suatu kesatuan yang berkaitan antara satu dengan yang lainnya. Menurut pandangan mereka bahwa konsep tentang alam raya ini terdiri dari tiga benua yaitu pertama, tingkatan atas disebut dengan benua atas, dan berpusat pada boting langit; kedua, benua tengah disebut lino artinya benua tengah yang dihuni oleh manusia; dan yang ketiga, adalah benua bawah disebut paratihi, artinya benua bawah dan dianggap berada di bawah air. Menurut Akip (2003 : 78), bahwa tanah dan hutan adalah "alamnya manusia". Tanah dan hutan merupakaan bagian dari makrokosmos menjadi hunian manusia dan mahluk hidup lainnya, sedangkan "angkasa/langit" dan "lautan/air". adalah alam misteri, tak diketahui (rahasia).

Unsur pentingnya lainnya terhadap lingkungan alam, yakni lebih banyak menitikberatkan pada pelestarian hutan. Kawasan hutan adat ri Kajang merupakan aset yang sangat berharga, sehingga keberadaan hutan ini selalu mendapat perlindungan dari seluruh warga komunitas adat Kajan. Pelestarian lingkungan alam termasuk hutan sangat 
ditentukan oleh kebijakan lingkungan yang dikaitkan dengan Pasang. Menurut konsep yang dipahami oleh masyarakat Patuntung bahwa manusia tanpa hutan tidak mungkin bisa hidup, karena hutan adalah sumber kehidupan, karena hutanlah yang mendatangkan hujan (anngontaki bosiya) dan menimbulkan mata-mata air dari dalam tanah (appakaanre timbusu'). Atas dasar itulah masyarakat adat Kajang menyimbolkan hutan itu sebagai paruparu dunia (paru-parunna linoa). Dalam kondisi seperti ini, masyarakat adat Kajang senantiasa harus selalu menjaga kelestarian lingkungan alam termasuk hutan, karena merusak hutan berarti merusak diri sendiri. Bahkan secara moral mereka mengatakan, "olo'-oloji anjo akkulle ammanraki boronga. Jari punna nia' tau ammanraki boronga sangkammajintu olo'-olo'a, "(hanya binatang yang dapat merusak hutan, jadi jika ada manusia yang sengaja merusak hutan berarti ia setara dengan binatang.

Begitu pula keterkaitannya dengan pandangan tentang Manusia; bahwa manusia menurut kepercayaan Patuntung adalah makhluk yang pertama diciptakan di antara tumbuhtumbuhan dan binatang, sedang bumi, air, dan matahari telah ada sebelum penciptaan manusia seperti disebutkan di atas, yakni ampatana, sedangkan tempat penciptaannya adalah di Tompo Tikka puncak Gunung Bawakaraeng. Olehnya itu, Bawakaraeng sungguh dipuja oleh mereka dengan anggapan bahwa disanalah tempat asal dan kejadian manusia.

Bagi masyarakat adat Kajang, dimana penganut aliran kepercayaan Patuntung pada prinsipnya terdapat dasar-dasar kepercayaan yang mereka imani dan percayai dalam hidupnya, yaitu (1) Percaya terhadap Turi'e A'ra'na (Tuhan Yang Maha Esa), (2) Percaya terhadap Ammatoa, (3) Percaya terhadap Pasang, (4) Percaya terhadap hari kemudian (allo riboko) dan (5) Percaya terhadap Takdir.

\section{a. Percaya terhadap Tuhan (Turi'e A'ra'na)}

Percaya kepada Turi'e A'ra'na merupakan konsepsi ketuhanan dalam ajaran Pasang. Turi'e A'ra'na adalah satu-satunya kekuasaan Yang Maha Mutlak dan merupakan sumber dari semua wujud. Bagi komunitas adat Kajang tumbuh konsep ketuhanan yang tunggal, mereka percaya bahwa apabila terdapat lebih dari satu Tuhan, maka dunia menjadi tidak tentram dan kacau. Seperti ungkapan dalam Pasang sebagai berikut: Turi'e A'ra'na ammantangi ri pangnge'rakkangn, Anrei niissei rie' na anre'na Turi'e A'ra'na, nake pala'doang. Artinya Turi'e A'ra'na tinggal berbuat/pada sesuatu kehendaknya (Tuhan melakukan sesuatu atas kehendaknya sendiri), tidak diketahui dimana adanya Turi'e A'ra'na tetapi kita minta rahmatnya, Padalo' $j i$ pole nitarimana pa'nga'ratta iya toje'na. Artinya diterima atau ditolaknya permintaan kita, dia yang tentukan.

Turi'e A'ra'na itu sendiri merupakan pula sebagai ungkapan dogmatis yang terdiri dari empat kata yang setiap kata mempunyai arti tersendiri. $T u$ adalah singkatan dari kata tau (bahasa konjo) yang berarti orang. "rie' berarti ada atau mempunyai. a'ra berarti kehendak, sedang kata na merupakan kata ganti milik. Jadi Turi'e A'ra'na berarti orang Yang Berkehendak atau Yang Maha Berkehendak (Mas Alim Katu, 2005 : 25). Hal tersebut sejalan dengan tulisan Ranre (1978) dan Badrum, (2006 : 4) yang menjelaskan, bahwa masyarakat adat Kajang mengakui Tuhan yang Esa atau Allah, namun di kalangan mereka pantang atau kasipalli menyebut Allah, akan tetapi menyebutnya dengan nama Karaeng Kaminang Kammaya atau dengan bahasa Kajang Karaeng Kaminang Jaria A'ra'na (Turi'e 
A'ra'na) artinya Tuhan Yang Maha Kuasa. Demikian pula nama-nama Nabi dalam hal ini Nabi Adam mereka sebut mula tau (manusia pertama), sedangkan Nabi Muhammad SAW mereka sebut tunisurona Turi'e A'ra'na (utusan Yang Maha Berkehendak).

$$
\text { Turi'e A'ra'na (Yang }
$$

Berkehendak) dapat memberikan tuntunan (Patuntung) dalam berperilaku, baik di dunia maupun di akhirat kelak. Mereka pula berkeyakinan bahwa ia merupakan pencipta dari segala sesuatu yang ada di dunia atas dan dunia fana atau dunia bawah. Ia menyerupai sesuatu, tetapi ia bukan sesuatu. Dialah yang memberi tuntunan dan kehidupan kepada seluruh makhluk yang ada di langit dan di dunia ini. Itulah sebabnya perlakuan terhadap para leluhur mereka dilakoninya dengan tidak memperhitungkan persoalan untung rugi, akan tetapi yang terpenting baginya mempertahankan adat dan budaya dalam berbuat menjadi suatu tuntutan ummat, seperti halnya pelaksanaan upacara atau ritual.

Adapun hakekat dari pada keberadaan Turi'e A'ra'na berada dalam semua ruang dan waktu, sehingga tidak diketahui secara tepat dimana dia berkedudukan. Namun apabila Turi'e A'ra'na berkenan memberi rahmat dan anugrah, maka akan sampai ke manusia sehingga meskipun kedudukan Turi'e A'ra'na tidak diketahui secara pasti. Namun jika manusia taat menjalankan perintah-Nya dan menjauhi apa yang dilarang maka akan bertemu dengan Turi'e A'ra'na. Sebagaimana isi Pasang, bahwa Siitte maki anjo punna nigaukangi passuroanna, na nililiangngi pappisangkanna. Artinya Manusia akan saling melihat/bertemu dengan Turi'e A'ra'na apabila dikerjakan perintahnya dan menjauhi larangannya.

Kemahakuasaan Turi'e A'ra'na dalam semesta ini tak terbatas, segala sesuatu yang dia kehendaki akan terjadi dan manusia tidak memiliki daya apapun terhadap segala keinginannya. Namun yang dapat diperbuat oleh manusia itu sendiri adalah permohonan doa kepada Turi'e A'ra'na dengan jalan berserah diri/pasrah melalui tapakkoro'. Kepercayaan dan penghormatan terhadap Turi'e A'ra'na merupakan keyakinan yang paling mendasar dalam agama adat. Masyarakat adat Kajang percaya bahwa Turi'e A'ra'na adalah "Tuhan" alam semesta dan pencipta segala sesuatu, Maha kekal, Maha mengetahui, Maha perkasa, dan Maha kuasa. Turi'e A'ra'na adalah causaprima yang berada pada kedudukan puncak penyembahan. Kekuatan supranatural, tetap mendapat perhatian yang kuat pada komunitas adat Kajang, akan tetapi masih di bawah status tertinggi Turi'e A'ra'na

\section{b. Percaya Terhadap Ammatoa}

Berdasarkan mitologi yang berkembang pada masayarakat adat Kajang dan ungkapan lainnya, menyebutkan bahwa perintah atau amanah dan larangan dari Turi'e A'ra'na akan disampaikan kepada seorang manusia yang mempunyai keistimewaan dan kelebihan-kelebihan. Orang tersebut karena kesuciannya maka nama aslinya pantang untuk diungkapkan. Sehingga mereka dipanggil menurut statusnya yaitu disebut Ammatoa. Seperti diungkapkan dalam Pasang bahwa Simemangna lino Amma riemo, yang artinya sejak dunia ada, Ammatoa sudah ada. Istilah Ammatoa tersebut bukanlah merupakan nama diri melainkan nama jabatan atau penamaan sesuai dengan statusnya. Amma adalah istilah Konjo artinya bapak, sedang istilah towa artinya tua atau yang dituakan. Pengertian bapak disini bukanlah pengertian menurut biologi yang berarti ayah kandung tetapi adalah pengertian bapak sebagai pemimpin atau kepala. Jadi Ammatoa 
berarti bapak tua atau bapak yang dituakan dengan kata lain pemimpin.

Selain penamaan Ammatoa dan statusnya sebagai pemimpin adat, juga dikenal dengan penamaan lain yakni Boheta yang berarti nenek atau moyang kita. Bohe artinya nenek sedang ta adalah merupakan kata ganti milik, jadi Boheta artinya nenek kita. Penamaan ini sesuai dengan statusnya sebagai nenek moyang manusia, sering pula disebut dengan nama mula tauwa yang berarti manusia pertama. Dalam hal pengangkatan Ammatoa sebagai pemimpin, nampaknya berkelanjutan terus menerus kepada setiap Ammatoa, selain dipilih berdasarkan keturunan juga berdasarkan aturan-aturan adat setempat, seperti dalam isi Pasang terdapat beberapa persyaratan dasar yang harus dipenuhi oleh seorang calon Ammatoa dalam bersifat dan berperilaku; (1) Sabbarapi na guru (kesabaran seorang guru), (2) Pesonapi na sanro (pesona seorang guru/peraamal), (3) Lambusupi na karaeng (kejujuran seorang raja), (4) Gattangpi na ada' (ketegasan memelihara adat). Selanjutnya, syarat lain yang harus dipenuhi oleh seorang Ammatoa yakni; (1) warga asli yang berasal dan berdiam di kawasan Ilalang Embayya, (2) tidak tau baca tulis, (3) tidak pernah meninggalkan kawasan Ilalang Embayya dan (4) Berasal dari keturunan baik-baik (tu kintarang). Dan setiap yang diangkat sebagai Ammatoa senantiasa menerima pengangkatan dari Turi'e A'ra'na, atau disebut dengan istilah Angguppa Pangngamaseang ri Turi'e A'ra'na.

Ammatoa dalam kapasitasnya sebagai pemimpin adat dalam kawasan adat Kajang, mempunyai andil besar dalam mengurusi masyarakatnya bersama dengan perangkat adat lainnya. Ammatoa sebagai pemimpin informal mempunyai fungsi dan tugas, yakni sebagai orang yang dituakan, artinya bahwa Ammatoa adalah pelindung, pengayom dan suri teladan bagi semua warga komunitas adat Kajang. Mereka sebagai penghubung manusia dan Turi'e A'ra'na, dan bertanggung jawab terhadap pelaksanaan kelestarian Pasang ri Kajang serta membawahi aturan-aturan adat yang bersumber dari Pasang dan norma-norma adat Kajang. Isi Pasang tersebut di dalamnya terdapat segala perintah Turi'e A'ra'na yang berbentuk pesan (tidak tertulis) kepada Ammatoa yang tidak dapat diubah, ditambah ataupun dikurangi dan harus dijalankan oleh Ammatoa, agar kehidupan masyarakat adat Kajang dapat berjalan dengan baik dan normal, baik katallassang lino (kehidupan di dunia) maupun allo ri boko (kehidupan akhirat kelak).

\section{c. Percaya Terhadap Pasang}

Percaya kepada Pasang merupakan unsur mutlak dalam sistem kepercayaan komunitas adat Kajang. Pasang diartikan sebagai misi (message), fatwa, nasihat, tuntunan yang dilestarikan turun temurun sejak mula tau (manusia pertama) sampai sekarang dengan melalui tradisi lisan, pantang ditulis sebagai sebab dapat terabaikan dalam perjalanan zaman. Pasang dipercayai sebagaai sumber dari Turi'e A'ra'na yang dinukilkan oleh tutowa mariolo (Ammatoa pertama) dan dilestarikan melalui pengawalan Ammatoa secara berkesinambungan. Berdasarkan cerita atau ungkapanungkapan yang terdapat dalam Pasang itu sendiri cukup banyak menyebutkan tentang penegasan untuk mempercayai isi dan kebenaran Pasang ri Kajang.

Selain itu Pasang menuntut kepada masyarakat pendukungnya untuk menerima semua ungkapan dan cerita Pasang sebagai doktrin atau ajaran. Sebab Pasang dan ajarannya mempunyai status yang tinggi, bahkan melebihi apa yang disebut Lontara ri Gowa atau apa yang disebut Kitta ri Luwu. Baik Kitta atau Lontara 
merupakan himpunan dan kumpulan dari pada ilmu pengetahuan suku-suku Bugis dan suku-suku Makassar. Bagi para pendukungnya, dimana Kitta atau Lontara dapat dipandang sebagai kitabkitab suci, sebab ajaran ini mengandung berbagai pengetahuan seperti kesaktian mantra-mantra dan semacamnya. Akan tetapi Pasang melebihi kesucian dari yang dimiliki oleh Lontara dan Kitta. Bahkan Pasang dipandang mempunyai nilai sakral yang melebihi kitab suci ummat Islam, sehingga kalau tidak menjalankannya perintah yang dikandungnya atau tidak mengindahkan apa yang dilarangnya merupakan suatu dosa.

Komunitas adat Kajang meyakini bahwa Pasang adalah sumber sejarah bagi komunitas adat Kajang, dan sekaligus mengandung prinsip-prinsip yang mengatur hubungan masyarakat adat Kajang dengan Turi'e A'ra'na, hubungan dengan sesama manusia dan hubungannya dengan lingkungan. Oleh karena itu, Pasang yang dinukilkan oleh tutowa mariolo (nenek moyang) yang diterima dari Turi'e A'ra'na tidak dapat ditambah atau dikurangi, sehingga posisi Pasang menempati posisi wahyu dalam agama samawi. Mempelajari Pasang merupakan sebagai tugas suci bagi warga masyarakat adat Kajang serta kemuliannya yang dikaitkan dengan tingkat penguasaannya dan ketaataannya terhadap Pasang. Kewajiban menuntut Pasang disebut mannuntungi dan penuntutnya disebut patuntung. Setiap pelanggaran Pasang bukan saja akan merendahkan derajat pelanggarnya di mata warga komunitas adat Kajang, melainkan akan membawa ekses bagi stabilitas sosial dan lingkungannya sekaligus, seperti bencana alam, rusaknya hasil pertanian, munculnya wabah penyakit dan terjadinya reaksi alam yang tidak bersahabat.

\section{d. Percaya Terhadap Hari Kemudian (allo ri boko)}

Terkait dengan percaya adanya hari kemudian, merupakan rangkaian dari kepercayaan terhadap Turi'e A'ra'na, mereka percaya bahwa imbalan segala perbuatan manausia akan diperoleh pada allo ri boko. Manusia meninggal dunia akan kembali kepada tumappare'na (Sang Pencipta). Menurut konsepsi Pasang bahwa hari kemudian (allo ri boko) atau hari akhirat adalah hari tempat kembalinya semua mahluk dan kembali menghadap Tuhan yang disebut dengan Tau Paretta (yang menjadikan). Dalam ajaran Pasang dunia ini hanyalah tempat tinggal sementara, sedang tempat tinggal yang kekal adalah akhirat yang disebut dengan istilah Allonjirengang atau allo ri boko. Apabila manuisa itu meninggal dunia menurut ajaran Pasang, maka mereka itu kembali ke asalnya atau kembali kepada Tuhan dengan segala sifat-sifatnya.

Masyarakat Kajang dituntun untuk senantiasa memelihara dirinya agar tetap konsisten dalam kebaikan selama hidup dengan melalui cara hidup appisona (pasrah), supaya kelak sesudah mati rohnya dapat diterima oleh Turi'e A'ra'na. Kehidupannya di akhirat akan ditentukan oleh perbuatannya selama masih hidup. Menurut pemahaman mereka, kalau semasah hidupnya seseorang mempunyai sifat rakus seperti babi, maka di akhirat nanti akan menjelma sebagai babi. Sedang bagi orang yang hidup sesuai dengan tuntunan Pasang, akan kembali ke allo $r i$ boko dan menghadap ke Turi'e A'ra'na dengan selamat. Sebaliknya, orang yang hidup tidak sesuai dengan ajaran Pasang rohnya akan ditolak Turi'e A'ra'na dan akan mendapatkan balasan sesuai dengan sifatnya di dunia (amminro ri sipa'-sipa'na). Menurut keyakinan mereka bahwa dunia hanya sekedar pammari-mariang (tempat 
istirahat sementara) sedangkan allo ri bokko disebut karakkang (tempat abadi). Sebagaimana dalam ungkapan disebutkan bahwa "anne linoa pammarmarianji, allo ribokko pammantangang karakkang". Artinya dunia ini hanya tempat istirahat, sedangkan hari kemudian tempat abadi.

\section{e. Percaya Terhadap Takdir / Nasib (turunganna)}

Percaya terhadap takdir (turunganna) merupakan rangkaian dari sistem kepercayaan dalam ajaran Pasang. Berdasarkan penuturanpenuturan lisan dalam konsep Pasang tentang adanya takdir atau nasib yang ditentukan oleh Tuhan atau Turi'e A'ra'na. Nasib baik atau buruk, miskin atau kaya semuanya itu tergantung kepada kehendak Yang Maha Kuasa. Menurut ajaran Pasang, semua orang akan memperoleh kekayaan yang disebut dengan Kalumannyang Kalupepeang jika dikehendaki oleh Tuhan. Seperti diungkapkan dalam Pasang : Kalumannyang akulei niuppa punna na'rakkangngi pamarenta nasaba' pamarenta sambungannai Turi'e A'ra'na nasaba' pamarenta iya angngissengisei nu haji nu kodi. Artinya, kekayaan itu dapat diperoleh jika dikehendaki oleh pemerintah (ammatoa) sebab pemerintah adalah penghubung dari Tuhan (Turi'e A'ra'na), ia mengetahui semua yang baik atau yang buruk. Selanjutnya, mengenai kemiskinan diungkapkan: Tau dodong kamase-mase Turunganna Angkua, yang artinya orang miskin itu memang sudah ditakdirkan demikian. Konsepsi Pasang mengenal juga adanya nasib atau takdir baik dan buruk, yang kesemuanya itu ditentukan oleh Turi'e A'ra'na.

Keyakinan tentang takdir lebih berorientasi ke fatalisme, dan terbangun beberapa prinsip hidup yang sangat menentukan kondisi masyarakatnya secara keseluruhan. Prinsip hidup kamase-masea (prihatin), pisona (pasrah/rida), tapakkoro (tafakkur) sabbara (sabar) merupakan refleksi dari kepercayaannya terhadap ketentuan nasib

\section{PENUTUP}

Masyarakat adat Kajang adalah sebuah komunitas adat yang mendiami sebuah kawasan adat (customary territory) di Desa Tanah Towa Kacamatan Kajang, Kabupaten Bulukumba, Provinsi Sulawesi Selatan. Pemukiman Komunitas Kajang terbagi atas dua kawasan yaitu Ilalang Embayya (kawasan adat Kajang dalam), dan Ipantarang Embayya (kawasan adat Kajang luar). Penduduk yang mendiami kawasan dalam, masih menjalankan sepenuhnya ajaran Patuntung sesuai isi Pasang. Sedangkan penduduk yang mendiami kawasan luar, meskipun masih tetap mengamalkan ajaran Pasang, akan tetapi lambat laun mengalami proses akulturasi dalam arti telah menyerap berbagai perubahan pola hidup, termasuk perubahan dalam pemahaman dan pengamalan ajaran agama Islam. Dalam kondisi demikian, maka kepercayaan Patuntung yang hidup dan tumbuh dalam kawasan adat Kajang bukan lagi budaya spiritual tradisional murni akan tetapi sudah mendapat pengaruh ide spiritual Islam.

Komunitas adat Kajang sangat loyal dalam mempertahankan tradisi ritual, karena adanya ketakutan supernatural tersendiri ketika tidak turut serta mendukung ritual. Mereka sangat yakin akan mengalami sebuah bala bencana, bilamana tidak lagi melakukan ritual sesuai tuntunan Pasang. Salah satu wujud ritual dari sistem kepercayaan Patuntung dapat dilihat dari pelaksanaan ritual Apparuntu Pangnganro atau sering disebut upacara a'doa (permohonan syukur). Ritual tersebut 
merupakan bentuk komunikasi dari ekspresi kesyukuran komunitas adat Kajang, dan sekaligus sebagai permohonan agar kehidupan mereka jauh lebih baik dari yang ada pada saat sekarang.

Pasang ri Kajang berisi tentang pesan-pesan, petuah-petuah, pedoman atau petunjuk hidup yang diwajibkan, demi kebahagian dunia dan akhirat. Patuntung mengajarkan manusia mendapatkan sumber kebenaran dari tiga pilar utama, yaitu menghormati Turi'e A'ra'na, tanah yang diperoleh dari Turi'e A'ra'na, dan nenek moyang mereka. Kepercayaan dan penghormatan terhadap Turi'e A'ra'na merupakan keyakinan yang paling mendasar dalam kepercayaan Patuntung. Masyarakat adat Kajang percaya bahwa Turi'e A'ra'na adalah Tuhan pencipta segala sesuatu, Maha kekal, Maha mengetahui, Maha perkasa, dan Maha kuasa.

Kepercayaan Patuntung itu, adalah refleksi dari isi Pasang, yaitu pesan-pesan dari Ammatoa Mariolo (Ammatoa pertama). Pesan ini merupakan keseluruhan pengetahuan dan pengalaman tentang segala aspek dan liku-liku yang berkaitan dengan kehidupan yang dipesankan secara lisan oleh nenek moyang mereka dari generasi ke generasi. Pasang wajib ditaati, dipatuhi, dan dilaksanakan oleh masyarakat adat Kajang. Jika mereka melanggar Pasang, akan terjadi hal-hal buruk dan bencana. Oleh karena itu, masyarakat adat Kajang menjadikan ajaran Pasang sebagai sumber kaidah, norma-norma dan hukum serta ramalan untuk suatu masa tertentu.

\section{DAFTAR SUMBER}

Ahmad, Abdul Kadir. 1991

Komunitas Ammatoa di Kajang Bulukumba, Studi Tentang Peranan Kepercayaan Terhadap Pelestarian Lingkungan Hidup. Tesis belum
diterbitkan.Ujung Pandang: Fakultas Pascasarjana Unhas

Akip, Yusuf. 2008.

Ammatoa (Komunitas Berbaju Hitam). Makassar: Penerbit Pustaka Refleksi. 2003.

Potret Manusia Kajang. Makassar: Pustaka Refleksi.

Badrum, H.P. 2006.

Sistem Kepercayaan Komunitas Adat Kajang Kabupaten Bulukumba. (Makalah disampaikan dalam seminar yang diadakan Oleh Balai Pelestarian Sejarah dan Nilai Tradisional. Makassar: tanggal 19 Juli 2006).

1985.

Eksistensi Komunitas Ammatoa Kajang. Ditinjau dari sudut pandang Struktur Fungsional. Laporan hasil penelitian. Ujung Pandang : BPLK.

Bustamin, Abd.Latif. 2011.

Teknik Inventarisasi Kepercayaan Komunitas adat. Makalah disajikan pada Bimbingan Teknis Pemataan Komunitas Adat. Bandung: Derektorat Kepercayaan Terhadap Tuhan Yang Maha Esa, Ditjen Nilai Budaya, Seni dan Film.

Glock, C.Y. \& Stark, R. 1966.

Religion and Society in Transition. Chicago: Rand Mc Nally und Company.

Hayat, Abd. 2006.

Kepribadian Orang Onta, Suatu Kajian Antropologi Psikologi. Disertasi. Makassar: Program Pascasarjana Universitas Hasanuddin. 
Haviland, 1999.

Pengantar Antropologi. Jakarta: Erlangga.

Koentjaraningrat. et. al. 1984.

Kebudayaan Mentalitas dan Pembangunan. Jakarta: Gramedia. 1991.

Beberapa pokok Antropologi Sosial. Jakarta : Dian Rakyat.

2002.

Kamus Istilah Antropologi. Jakarta: Progress kerja sama dengan Pusat Bahasa Depdiknas.

Mas Alim Katu. 2005.

Tasawuf Kajang. Makassar: Pustaka Refleksi (Lembaga Penelitian dan Penerbitan buku).

Manda, Darman. 2007.

Komunitas Adat Karampuang (Suatu Perspektif Antropologi Agama). Makassar: Penerbit Universitas Negeri Makassar (UNM).

Mukhlis, Kathrin R, 1985.

Agama dan Realitas Sosial. Makassar: Lembaga Penerbitan Unhas (Lephas).

Palammai, Ramli. 2012.

Sejarah Eksistensi Ada'Lima Karaeng Tallua ri Kajang. Bulukumba: Dinas Kebudayaan dan Pariwisata Kabupaten Bulukumba.

Renre, Abdullah. 1978.

Patuntung di Kecamatan Sinjai Barat. Suatu Tinjauan Sosio Kultural. Skripsi. Ujung Pandang : Sinar Grafika.

Suarsana, IMade. 2012.

Kepercayaan Komunitas Adat di Desa Watuhadang, Kecamatan Umalulu, Kabupaten Sumba Timur. (Dimuat dalam Jurnal Penelitian Sejarah dan Nilai Tradisonal. Bali, NTB dan NTT), Volume 19 Nomor 1 Maret 2012. BPSNT Denpasar.

Tanako, B.S. 1984.

Struktur dan Proses Sosial. Suatu Pengantar Sosiologi Pembangunan, Jakarta: Rajawali

Usop, KMA, M. 1978.

Pasang ri Kajang, Kajian Sistem Nilai di Benteng Hitam Ammatoa.Ujung Pandang: Pusat Latihan Penelitian Ilmu-IlmuSoaial. 